\title{
69. Bir özde çeviri örneği The City of the Sultan and Domestic Manners of the Turks in 1836 ve aslına çevirilerinde kenti temsil eden göstergelerin aktarımı1
}

\section{Sündüz ÖZTÜRK KASAR 2}

Kübra ÇELİK3

\begin{abstract}
APA: Öztürk Kasar, S.; Çelik, K. (2021). Bir özde çeviri örneği The City of the Sultan and Domestic Manners of the Turks in 1836 ve aslına çevirilerinde kenti temsil eden göstergelerin aktarımı. RumeliDE Dil ve Edebiyat Araşturmalar Dergisi, (23), 1067-1084. DOI: 10.29000/rumelide.950011.
\end{abstract}

\section{$\ddot{\mathbf{O} z}$}

İngiliz seyyah ve yazar Julia Pardoe, 1835 yılında geldiği Osmanlı topraklarına ilişkin gözlemlerini The City of the Sultan and Domestic Manners of the Turks in 1836 adll eserde okuyucuyla buluşturur. Seyahatname niteliği taşıyan bu eser döneminin az sayıdaki kadın eserlerinden biri olmasının yanı sıra bir yabancı gözüyle İstanbul kenti başta olmak üzere Osmanlı topraklarındaki sosyal, kültürel ve siyasi yaşama dair derinlemesine sunduğu ipuçlarıyla dikkat çeker. Oluşturulduğu dil ve kültür bağlamıyla, yazıldığı dil ve kültür bağlamı farklı olan bu eser, İngiliz okura özgün bir eser olarak sunulsa da Türk kültürüne ait göstergelerin İngiliz kültürüne mensup bir yazar tarafından alımlanıp, İngiliz dilinde kaleme alınması eserin içerdiği zihinsel çeviri işlemine işaret eder. Bu bakış açısıyla ele alınan The City of the Sultan and Domestic Manners of the Turks in 1836 adlı eser bir çeviri metin olarak kabul edilmekte ve Sündüz Öztürk Kasar'ın ortaya koyduğu "özde çeviri” kavramı temelinde değerlendirilmektedir. Eserin Bedriye Şanda ve Banu Büyükkal tarafından Türkçeye yapılan çevirileri ise Öztürk Kasar'ın öne sürdüğü “aslına çeviri” kavramı odağında, özde çeviri eser ile karşılaştırmalı olarak ele alınmaktadır. Bu bağlamda mevcut çalışmanın amacı, Julia Pardoe'nun Osmanlı topraklarına ait göstergeleri Batılı okura ne şekilde yansıttığını ve göstergelerin Türk okura nasıl sunulduğunu yani aslına nasıl çevrildiğini açığa çlkararak kaynak ve erek metinlerde kent göstergelerinin geçirdiği dönüşümü ortaya koymaktır

Anahtar kelimeler: Özde çeviri, aslına çeviri, çeviri göstergebilimi, kent göstergebilimi, The City of the Sultan and Domestic Manners of the Turks in 1836

\section{The transfer of the urban signs in The City of the Sultan and Domestic Manners of the Turks in 1836 as an example of watermark translation and in its retro- translations}

\begin{abstract}
Julia Pardoe, an English traveler and writer, wrote her observations of Ottoman lands where she arrived in 1835 in her book The City of the Sultan and Domestic Manners of the Turks in 1836. The book which has the characteristics of a travel book has attracted the attention of the reader not only
\end{abstract}

Bu makale, Kübra Çelik’in Yıldız Teknik Üniversitesi Sosyal Bilimler Enstitüsü Diller ve Kültürlerarası Çeviribilim Doktora Programı'nda Prof. Dr. Sündüz Öztürk Kasar’ın danıșmanlığında hazırladığı doktora tezinden üretilmiștir.

Prof. Dr., Yıldız Teknik Üniversitesi, Fen Edebiyat Fakültesi, Batı Dilleri ve Edebiyatı, Mütercim Tercümanlık (Fransızca) (İstanbul, Türkiye), sunduzkasar@gmail.com, ORCID ID: oooo-ooo1-9642-7073 [Araştırma makalesi, Makale kaylt tarihi: 14.04.2021-kabul tarihi: 20.06.2021; DOI: 10.29000/rumelide.950011]

Öğr. Gör., Orta Doğu Teknik Üniversitesi, Yabancı Diller Yüksekokulu (Ankara, Türkiye), kubraavcicelik@gmail.com, ORCID ID: 0000-0003-2611-7082

RumeliDE Dil ve Edebiyat Araștırmaları Dergisi Osmanağa Mahallesi, Mürver Ciçeği Sokak, No:14/8 Kadıköy - ISTANBUL / TÜRKIYE 34714 e-posta: editor@rumelide.com tel: +90 $5057958124,+902167730616$
Address

RumeliDE Journal of Language and Literature Studies

Osmanağa Mahallesi, Mürver Çiçeği Sokak, No:14/8

Kadıköy - ISTANBUL / TURKEY 34714

e-mail: editor@rumelide.com,

phone: +90 505 7958124, +90 2167730616 
The transfer of the urban signs in The City of the Sultan and Domestic Manners of the Turks in 1836 as an example of watermark translation and in its retro-translations / S. Öztürk Kasar; K. Çelik (pp. 1067-1084)

\begin{abstract}
because it was one of the rare books of its time written by a women but also it includes detailed traces of social, cultural and political life in Ottoman lands, especially in Istanbul through the eyes of a foreigner. Although the book is presented to English reader as an original book, it includes observations of signs related to Ottoman culture through the eyes of an English traveler and these observations were written in English. The text, therefore, indicates a mental translation process in it. With this point of view, The City of the Sultan and Domestic Manners of the Turks in 1836 is accepted as a translation and examined through Sündüz Öztürk Kasar's concept of watermark translation. In addition, Turkish translations of the book by Bedriye Şanda and Banu Büyükkal are examined through Sündüz Öztürk Kasar's concept of retro-translation with a comparison of the original book which is a watermark translation. Therefore, the aim of this study is to present the transformation of the urban signs in the source book and the target books by examining how the signs that belong to Ottoman lands were transferred to English readers and how these signs turned back to Turkish readers or translated back to their source.
\end{abstract}

Keywords: Watermark translation, retro-translation, semiotics of translation, urban semiotics, The City of the Sultan and Domestic Manners of the Turks in 1836

\title{
1. Giriş
}

İnsanın yaradılış gereği “öteki”ne duyduğu merak onu bu konuda araştırma ve öğrenmeye teşvik etmiştir. Farklı coğrafyalara yapılan yolculuk neticesinde bu coğrafya ve orada yaşayanlar ile ilgili kaleme alınan yazılar seyahatname ya da gezi yazıları olarak nitelendirilmektedir. Seyahatnameler, okurlarına farklı bir coğrafyanın doğal özelliklerinden kültürel unsurlarına, tarihi mirasından gündelik yaşamına uzanan bir göstergeler mozaiği sunar. Seyahatname yazarı söz konusu göstergeleri bu topraklara yabancı olan okura kendi algılama süzgecinden geçirerek aktarır (Asıltürk, 2009, 912-913).

Bu araştırmanın bütüncesini oluşturan The City of the Sultan and Domestic Manners of the Turks in 1836 adlı eser de türü itibarıyla bir seyahatname niteliği taşımaktadır. Söz konusu eser bir İngiliz seyyah ve yazar Julia Pardoe tarafından kaleme alınmıștır. Julia Pardoe, babasının işi dolayısıyla 1835'te geldiği ve dokuz ay kaldığı İstanbul'da hem daha önceki seyahat tecrübeleri hem de babasının itibarlı mesleği sayesinde haremlerden hamamlara, camilerden dergâhlara o dönemde bir gayrimüslimin girmesinin epey güç olduğu pek çok yere konuk olur. Osmanlı başkentinin doğal güzelliklerini, eğlence yerlerini, anıtlarını, çarşılarını dolaşan; çeşitli sosyal düzeydeki kişilerin konaklarında gündüz ve gece konuk olan Julia Pardoe tüm bu deneyimlerden edindiği bilgileri kendi gözünün gördüğü ve hissettiği biçimde bu seyahatnamesinde toplar. Gözlemlerini ön yargılardan uzak ve tarafsız bir biçimde yansıttığını ifade eden Pardoe, Avrupa'da o zamana değin var olan Doğu'ya yönelik kemikleşmiş ön yargıları silmeyi amaçlar ( Pardoe, 2017, XXXII-XXXIII). Eser, Osmanlı başkenti ve bu kente ait öğelerin bir Batılı tarafından gözlemlenip İngiliz dilinde kaleme alınması nedeniyle, başka bir ifadeyle oluşturulduğu dil ve kültür bağlamıyla yazıldığı dil ve kültür bağlamının farklı olması nedeniyle araştırma nesnesi olarak seçilmiştir. Bu bağlamda çalışmanın temel sorunsalı Julia Pardoe'nun Osmanlı topraklarına ait kent göstergelerini ne şekilde yansıttığını ve bu kent göstergelerinin Türk okura yani aslına nasıl çevrildiğini açığa çıkararak, bu göstergelerin kaynak ve erek metinlerde geçirdiği dönüşümü ortaya koymaktır. Kaynak ve erek kavramlarının iç içe geçtiği söz konusu araştırma nesnelerinin betimsel bir yaklaşımla irdelendiği bu çalışmada, çeviribilime yeni bir soluk getiren özde çeviri ve aslına çeviri kavramlarının farklı bir metin türü üzerinden ele alınmalarıyla çeviri göstergebilimi alanına katkı sağlanması hedeflenmektedir.




Çalışmada öncelikle kavramsal çerçeveyi oluşturan özde çeviri ve aslına çeviri kavramları detaylandırılmaya çalışılacaktır. Kavramsal çerçeve içinde Öztürk Kasar tarafından özde çeviri ile ilişkili olarak öne sürülen kent göstergelerinin sınıflandırılmasına da yer verilecek, ardından özde çeviri metin aslına çevirileriyle, diğer bir deyişle, Türkçe çevirileriyle karşılaştırmalı olarak okunacaktır. Bu okumada özde çeviri kabul edilen metinde yazarın kent göstergeleri üzerindeki zihinsel çeviri belirtilerinin izi sürülecek ve çevirmenlerin bu göstergeler üzerindeki kararları irdelenecektir.

\section{Kavramsal çerçeve}

Osmanlı kültürü, gündelik yaşamı, gelenek görenekleri gibi Doğu'ya özgü pek çok ayrıntı çerçevesinde șekillenen The City of the Sultan and Domestic Manners of the Turks in 1836 adlı eser yukarıda da belirttiğimiz gibi Batılı yazar Julia Pardoe tarafından kaleme alınmıştır. Pardoe, hayranlık duyduğu, kendisine ait olmayan bu topraklara bir yabancı gözüyle bakmış ve bu topraklara özgü gözlemlerini yine bu topraklara yabancı kimselere kendi dilinde aktarmıștır. Bulunduğu topraklarda yabancı olarak nitelendirebileceğimiz bir yazarın gözlemlediği coğrafyayı o coğrafyada konuşulandan farklı bir dile aktarımı Öztürk Kasar’ın ortaya koyduğu özde çeviri (2012, 2020,2021) kavramını akla getirmektedir.

Öztürk Kasar çeviri göstergebilimini yeni bir kavram olan “özde çeviri” kavramıyla buluşturur. İlk olarak Fransızca kaleme alınan "Traduction de la ville sous le point de vue sémiotique: Istanbul à travers ses signes en trois langues (2012) " başlıklı makalede "traduction en filigrane" olarak ortaya koyulan bu kavram daha sonra Türkçeye "özde çeviri” olarak aktarılmıştır. "Özde çeviri” oluşturulduğu dil ve kültür bağlamında özgün bir eser olarak üretilen ancak özünde zihinsel bir çeviri işlemi barındıran eserlere gönderme yapar. Diğer bir ifadeyle, eserin yansıttığı dil ve kültür bağlamı oluşturulduğu dil ve kültür bağlamından farklıdır. Yazar eserini kaleme alırken zihninde bir dil ve bir kültürden bir diğerine çeviri yapar ve bu çeviri işlemi kâğıt paralar üzerindeki filigran gibi metnin dokusuna işler. Öteki kentler, uzamlar, tarihi ve toplumsal olaylar, şahıslar ve bunları temsil eden özel ad göstergeleri üzerine temellenen özde çeviri kavramı, içinde barındırdığı zihinsel çeviri işlemi neticesinde özgün eser okurunda çeviri okuyor hissi uyandırabilir ( Öztürk Kasar, 2020, 3-4). Çalışmanın bütüncesini oluşturan The City of the Sultan and Domestic Manners of the Turks in 1836 (1845) adlı eser de bir İngiliz hanımefendisi olan Julia Pardoe' nun 1835 yllında Osmanlı başkenti İstanbul ile Bursa'ya yaptığı ziyaretlerinde edindiği bilgileri bir yabancı gözüyle zihinsel bir çeviri işlemine tabi tutup yazmasıyla oluşmuştur. Dolayısıyla söz konusu eser de bir "özde çeviri” örneği olarak nitelendirilebilir.

Öztürk Kasar $(2020,4)$, özde çeviri üretiminin iki türde gerçekleşebileceğinden söz eder: “Öz bağlamdan yabancı bağlama giden özde çeviriler" ve "Yabancı bağlamdan öz bağlama giden özde çeviriler" (Öztürk Kasar, 2020, 5). Nitekim Pardoe' nun kendisine yabancı olan bir bağlamı İngilizce dilinde kaleme alarak öz bağlamına taşıdığı seyahatname bu bağlamda değerlendirilebilir.

Öztürk Kasar (2020, 5), "Yabancı bağlamdan öz bağlama giden özde çeviriler" in yabancı bir dilden anadile doğru bir zihinsel çeviri işlemi içerdiğini belirtir. Yazarın böyle bir metni kaleme alma nedeni yabancı kültüre duyduğu hayranlık, yabancı kültürü hor görme ya da tarafsız bir yaklaşım olabilir. Nitekim Pardoe da hayranlıkla gözlemlediği Osmanlı topraklarını kaleme aldığı seyahatnamesinde çok kez yaptığı tarafsızlık vurgusuyla dikkat çeker. Hatta öyle ki bu toprakları ve bu toprakların insanlarını tümüyle yansız ve dürüst bir biçimde nakletme arzusuyla daha geniş bir alanda planladığı seyahatini yalnızca İstanbul ve Bursa ile sinırlı tutar:

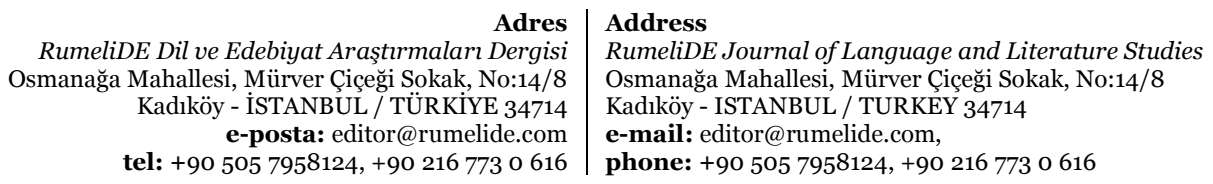


The transfer of the urban signs in The City of the Sultan and Domestic Manners of the Turks in 1836 as an example of watermark translation and in its retro-translations / S. Öztürk Kasar; K. Çelik (pp. 1067-1084)

“...Türkiye gibi yapılanmış bir memlekette hızlı ve sathi bir tetkik yapmakla kifayet edersem, iyi bir tarih müellifi olmayacağımı gördüm. Șark maceramın tamamının İstanbul'da ve Anadolu'nun ufak bir parçasında geçmiş olması herhalde bu inancıma bağlı olmalı. Ama okuyucularıma Türklerin adetleriyle ve gündelik hayatlarıyla alakalı şimdiye kadar edinebildiklerinden daha dürüst ve şumüllü bir kavrayıș arz etme gayretinde netice alabildiğimi bilirsem, bu sukut-ı hayalim fazlasıyla telafi edilmiş olur (Pardoe, 2017, XXXIII).”

Öztürk Kasar (2020, 5), her ne sebeple olursa olsun bu tür bir metin kaleme alınırken ötekinin dünyasının çok iyi tanınması gerektiğini belirtir. Ancak diğer kültür her ne kadar iyi tanınsa da metin üzerinde, algılama farklılıkları neticesinde oluşan bazı izlere rastlanabilir. Nitekim Pardoe, bu tür izlerin oluşabileceği sinyallerini daha eserinin en başından “takdim” bölümünden vermektedir:

“Türkiye'nin dili başlı başına ciddi bir engel. Herhangi bir Avrupa diline hiçbir surette benzemediği için, yerli ile yabancı arasında tabii bir duvar yükseliyor. Bu duvar, üçüncü bir şahsın tercüman olarak araya girmesiyle ancak kısmen ortadan kalkabiliyor (Pardoe, 2017, XXXI)"

Kaynak metin içerdiği zihinsel çeviri işlemiyle bir özde çeviri olarak adlandırıllyorken, eserin oluşturulduğu kültür bağlamına dönüşü, bir diğer ifadeyle kaynak olarak nitelendirebileceğimiz metnin ereğe aktarımı ne şekilde nitelendirilir? Öztürk Kasar (2020, 7), bu bağlamdaki çeviriler için "aslına çeviri" kavramını öne sürer. Aslına çeviri, yazarın zihninde gerçekleşen çeviri işleminin çıkış diline geri dönüşü olarak nitelendirilir. Kaynak metnin de bir çeviri olarak nitelendirildiği, erek metnin alışılmış çeviri tanımından farklı olarak bir ereğe değil kaynağa döndüğü bu tür metinlerde kaynakerek metin ile çevirmen- yazar adlandırmalarının iç içe geçtiği söylenebilir.

Öztürk Kasar (2020), “özde çeviri” kavramının yabancı bir coğrafyada geçen olayları konu edinmesi nedeniyle göstergebilimin farklı bir alanı olan kent göstergebilimini de araştırmaya dahil ettiğini ifade eder. Kent göstergebilimine odaklanan ilk isimlerden biri Roland Barthes'dır. Barthes (1970-71), "Sémiologie et urbanisme" adıyla yayımlanan ve Göstergebilimsel Serüven (1993) adlı kitap içerisinde "Göstergebilim ve şehircilik” başlığıyla Türkçeye çevrilen makalesinde kent göstergeleri aracılığıyla kentlerin okunabilirliğine odaklanır ve bir kent göstergebiliminin ne şekilde mümkün olabileceğini sorgular. Barthes (1993, 173)'a göre bir kent göstergebilimi anlayışının oluşmasının temelinde o kenti anlamlandırmak yatar.

Barthes'ın görüşleri temelinde kent okumalarından birini gerçekleştiren ve bunu çeviri alanıyla buluşturan Sündüz Öztürk Kasar (2020, 9), kentin anlam taşıyan pek çok farklı katmandan oluştuğunu belirtir. Öztürk Kasar $(2020,10)$, bu katmanları oluşturan ve bir kenti temsil eden göstergeleri üç ana başlıkta toplar; her ana başlık kendi içinde alt başlıklara ayrılmaktadır:

“1. Özel ad göstergeleri:

a. Yer adları ve su adları

b. Kiși adları ve lakapları

c. Kurum ve işletme adları

2. Tarihsel göstergeler:

a. Tarihi anitlar

b. Tarihi olaylar

c. Tarihi şahsiyetler

3. Kültürel göstergeler:

a. Toplumsal yaşam ve günlük alışkanlıklar

RumeliDE Dil ve Edebiyat Araştırmaları Dergisi Osmanağa Mahallesi, Mürver Ciçeği Sokak, No:14/8 Kadıköy - ISTANBUL / TÜRKIYE 34714 e-posta: editor@rumelide.com tel: +90 505 7958124, +90 2167730616
Address

RumeliDE Journal of Language and Literature Studies Osmanağa Mahallesi, Mürver Çiçeği Sokak, No:14/8

Kadıköy - ISTANBUL / TURKEY 34714

e-mail: editor@rumelide.com,

phone: +90 $5057958124,+902167730616$ 
b. Ev yaşantısı ve düzeni, mobilyalar ve dokumalar

c. Yemek kültürü

d. Giysiler, şapkalar ve diğer aksesuarlar

e. Ulaşım araçları

f. Ölçü birimleri (Öztürk Kasar, 2020, 10).”

Bu çalışmada kent göstergelerinin sınıflandırılmasında Öztürk Kasar (2020)'ın öne sürdüğü katmanlar temel alınmıştır. Bütüncenin sunduğu veriler doğrultusunda mevcut başlık ve alt başlıklara eklemeler yapılmış, veri elde edilemeyen kategoriler kullanılmamıştır.

\section{3. Özde çeviri ve aslına çeviri odağında inceleme metinleri}

"Özde çeviri” kavramsal altyapısıyla temellenen bu çalışmada Julia Pardoe'nun The City of the Sultan and Domestic Manners of the Turks in 1836 adlı eseri Osmanlı toplumuna ait göstergelerin bir Batılı tarafından İngiliz dilinde kaleme alınması, bir başka deyişle, oluşturulduğu dil ve kültür bağlamıyla yazıldığı dil ve kültür bağlamının birbirinden farklı olması nedeniyle bir özde çeviri olarak kabul edilmektedir. Eserin 1837, 1838, 1845 ve 1854 yıllarına ait basımları bulunmaktadır. Farklı yıllara ait basımlar arasında büyük farklılıklar olmamakla birlikte ilk basım iki cilt, diğer üç basım ise her biri üçer cilt olarak basılır. Bu çalışmada özde çeviri kabul edilen eser Türkçe çevirileriyle karşılaştırmalı olarak okunmuş ve cilt sayısı ile içerdiği bölümler dikkate alınarak 1845 basımı araştırma nesnesi olarak ele alınmıștır.

Bunun yanı sıra kavramsal çerçevenin bir diğer ayağını oluşturan "aslına çeviri” kavramı kaynak metnin Türkçe çevirileri üzerinden irdelenecektir. Eser Türkçeye iki farklı çevirmen, Bedriye Şanda ve Banu Büyükkal, tarafından beş farklı adla çevrilir. İlk olarak 1967 yılında Bedriye Şanda tarafından Yabancı Gözü ile 125 yıl Önce Istanbul adıyla çevrilen eser, 1997 yllında 18.yy'da İstanbul adıyla yeniden okuyucuyla buluşur. Bu eser 750 sayfa ve üç ciltten oluşan özgün eserin 212 sayfadan oluşan kısaltılmış bir çevirisidir. Daha sonra kitabın bir diğer çevirmeni olan Banu Büyükkal tarafından yapılan çeviri ilk kez 1999 yılında Boyner Grup Yayıncılık tarafından Miss Pardoe Gözüyle 19. yy Osmanlı Yaşantısı adıyla yayımlanır. Aynı çeviri 2004 yılında Şehirlerin Ecesi İstanbul: Bir Leydinin Gözüyle 19.yy'da Osmanlı Yaşamı adıyla Kitap Yayınevi aracılığıyla yeniden okuyucuyla buluşur. 544 sayfadan oluşan bu çevirinin eksiksiz, tam metin olduğu Yayıncı Notunda belirtilir. Türkiye İş Bankası Yayınları 2010 ve 2017 yıllarında aynı eseri yine Banu Büyükkal çevirmenliğinde Sultanlar Şehri Ístanbul adıyla sunar. Araştırmada kullanılan inceleme metinlerinin künyesi aşağıdaki tabloda yer almaktadır:

Tablo 1. İnceleme metinleri

\begin{tabular}{|l|l|}
\hline Özde çeviri & $\begin{array}{l}\text { Julia Pardoe,1845, The City of the Sultan and Domestic Manners of the Turks in } \\
\text { 1836, London: Henry Colburn. }\end{array}$ \\
\hline Aslına çeviriler & $\begin{array}{l}\text { Julia Pardoe, 1967, Yabancı Gözü ile } 125 \text { yıl Önce Istanbul, çev. Bedriye Şanda, } \\
\text { İstanbul, İnkllap ve Aka Kitabevleri Koll. Şti. } \\
\\
\text { Julia Pardoe, 2017, Sultanlar Şehri İstanbul, çev. Banu Büyükkal, İstanbul, Türkiye İş } \\
\text { Bankası Yayılar. }\end{array}$ \\
\hline
\end{tabular}

Eserin Bedriye Şanda tarafından yapılan çevirileri 1967, 1997 yıllarında farklı adlarla yayımlanmış olmalarına rağmen büyük oranda benzerlikler gösterir. Bu nedenle eserin Türkçeye yapılan ilk çevirisi olan 1967 basımı araştırmaya dahil edilmiştir. Banu Büyükkal tarafından yapılan ve üç farklı adla




The transfer of the urban signs in The City of the Sultan and Domestic Manners of the Turks in 1836 as an example of watermark translation and in its retro-translations / S. Öztürk Kasar; K. Çelik (pp. 1067-1084)

yayımlanan çevirilerden ilk ikisi büyük oranda aynı metin iken Sultanlar Şehri İstanbul başlıklı çeviri kullanılan yan metinler ve bütünce ile tarihe uygun dil kullanımı sebebiyle çevirmen görünürlügünün ön plana çıktığı bir basım olması ve özde çeviri metnin Türkçeye yapılan son çevirisi olması nedenleriyle araştırma nesnesi olarak tercih edilmiştir.

\section{Karşılaştırmalı metin incelemeleri}

Bu çalışmada Julia Pardoe'nun The City of the Sultan and Domestic Manners of the Turks in 1836 (1845) başlıklı eseri ile Türkçe çevirileri Yabancı Gözü ile 125 yıl Önce Istanbul (1967) ve Sultanlar Şehri İstanbul (2017) karşılaştırmalı olarak okunarak kenti temsil eden göstergelerin geçirdiği dönüşümler "özde çeviri” ve "aslına çeviri” kavramları aracılığıyla saptanmaya çalışılmıştır. Yukarıda da belirttiğimiz gibi kenti temsil eden göstergelerin sınıflandırılmasında Öztürk Kasar (2020, 10)'ın öne sürdüğü sınıflandırma temel alınmış, bütüncenin el verdiği ölçüde güncellemeler yapılmıştır. Osmanlı İmparatorluğu'na başkentlik etmiş İstanbul ve Bursa kentleri üzerinde yoğunlaşan göstergeler niteliklerine uygun kategorilere ayrılarak eserin içerdiği zengin gösterge evreni ortaya koyulmaya çalışılmıştır.

\section{1. Özel adların aktarımı}

Çalışmanın bu bölümünde özde çeviri olarak kabul edilen eserde bulunan yer adları ile kişi lakaplarına yer verilmiş, bu özel adların Batılı okura aktarıldığı özde çeviride ve çıkış kültürüne döndüğü aslına çevirilerinde geçirdiği dönüşümler ortaya koyulmaya çalışılmıştır.

\section{Örnek 1.}

Pardoe'nun ziyaret ettiği Osmanlı toprakları yalnızca İstanbul'la sınırlı değildir. O günlerde İstanbul'dan rahatlıkla görülebilen Uludağ’n bulunduğu Bursa şehri de Pardoe'nun merakını celbetmektedir. Bunun üzerine bir gün babasıyla Haliç’ten bindiği ada teknesiyle Mudanya’ya doğru seyahat eder. Bursa seyahatinde pek çok tarihi yapının yanında Uludağ’ da yakından görmek isteyen Pardoe zorlu bir yolculuğa çıkar. Pardoe, bugün Uludağ olarak andığımız Bursa'nın önemli turizm merkezlerinden biri olan oluşumu "Mount Olympos" olarak anar ve onu "the dwelling of the Gods ( Tanrıların meskeni)4” olarak tanımlar.

Tablo 2. Yer adlarının aktarımı

\begin{tabular}{|c|c|c|}
\hline İnceleme Metinleri & İncelenen Bağlam & $\begin{array}{l}\text { Çözümleme } \\
\text { Öğeleri }\end{array}$ \\
\hline Pardoe, 1845, cilt 2: 191 & $\begin{array}{l}\text {...and returns home without smoking a pipe on the summit of } \\
\text { Mount Olympus, has, according to the declaration of the } \\
\text { natives,"seen nothing"...I set forward, accompanied by a Greek } \\
\text { gentleman, (with whose charming family we had formed a } \\
\text { friendship, and who was himself well calculated, by his scientific } \\
\text { acquirements, to enhance the enjoyment of the expedition) our } \\
\text { servant, and a guide, for the dwelling of the Gods. }\end{array}$ & $\begin{array}{l}\text { Mount Olympus } \\
\text { the dwelling of } \\
\text { the Gods }\end{array}$ \\
\hline Pardoe, 1967,137 & $\begin{array}{l}\text {...Türkiye'nin her tarafinı gördükten sonra, Uludağ’ın zirvesinde bir } \\
\text { çubuk içmeden dönerse, yerlilerce "Hiçbir şey görmemiş" demektir. } \\
\text { Bir Rum centilmen, hizmetkarımız ve bir rehber olmak üzere } \\
\text { Allah’ın mekânı dedikleri yere doğru ilerlemeye başladık. }\end{array}$ & $\begin{array}{l}\text { Uludağ } \\
\text { Allah'ın mekânı }\end{array}$ \\
\hline Pardoe, 2017, 394 & ...fakat vatanına Keşiş Dağı'nın zirvesinde bir çubuk tüttürmeden & Keşiș Dağ \\
\hline
\end{tabular}

$4 \quad$ Çeviri tarafımızca yapılmıştır.

RumeliDE Dil ve Edebiyat Araşttrmaları Dergisi Osmanağa Mahallesi, Mürver Çiçeği Sokak, No:14/8 Kadıköy - İSTANBUL / TÜRKIYE 34714 e-posta: editor@rumelide.com tel: +90 505 7958124, +90 2167730616
Address

RumeliDE Journal of Language and Literature Studies Osmanağa Mahallesi, Mürver Çiçeği Sokak, No:14/8

Kadıköy - ISTANBUL / TURKEY 34714

e-mail: editor@rumelide.com,

phone: +90 505 7958124, +90 2167730616 


\begin{tabular}{|l|l|l|}
\hline & $\begin{array}{l}\text { dönmüș kişi buralıların gözünde "hiçbir şey görmemiş" } \\
\text { sayıllyor.Elbette benim bu gafil yolculardan biri olmam söz konusu } \\
\text { değildi... Rum bir bey, hizmetkârımız ve bir kıllavuz eşliğinde } \\
\text { tanrıların dağına doğru yola çıtım. }\end{array}$ & Tanrıarın dağı \\
\hline
\end{tabular}

Uludağ’n tarihine baktığımızda Bizans öncesinde Olympos olarak adlandırıldığını ve pek çok manastırın burada yapılanması nedeniyle Osmanlı döneminde "Keșiş dağı" olarak adlandırıldığını gördük. Heredot'un kitaplarında "Mysia Olympos" olarak anılan dağ, bölgenin Roma imparatorluğu hakimiyetine girmesi ve Hristiyanlığın bölgede resmi din kabul edilmesiyle birlikte pek çok manastıra ev sahipliği etmeye başlar. Osmanlı'nın Bursa'yı fethiyle birlikte ise dağda yer alan pek çok manastır ve bu manastırlarda yaşayan keşişler dolayısıyla "Keșiş Dağı" adıyla anılır. 1925 yılında Uludağ ile ilgili bir yazı kaleme alan milletvekili Osman Şevki Bey yazısında artık burada herhangi bir keşiş yaşamadığı için "Keşiş Dağı" adlandırmasının uygun olmadığı görüşünü bildirir ve dağın yapısına uygun olarak "Uludağ” isminin verilmesini önerir (Beșe, 2017). Bu öneri üzerine "Keşiş Dağı" artık Türkçede "Uludağ" olarak nitelendirilmeye başlar. Bu bilgiler doğrultusunda Pardoe'nun Bursa ziyareti esnasında "Keşiş Dağı" olarak adlandırılan bu dağı "Olympos" adıyla nakletmesinin mitolojik anlatıların etkisiyle yapılan bir zihinsel çeviri işlemine işaret ettiği söylenebilir. Nitekim Pardoe, bu dağa eklediği “Tanrıların meskeni” ifadeleriyle de bu durumu destekler niteliktedir.

Aslına çeviri eserlerde ise çevirmenlerin farklı tercihleri dikkat çekmektedir. Şanda "Olympos" ismi için dağın günümüzdeki adı olan "Uludağ” tercih etmiştir. Ancak anlatı 1836 Osmanlı'sında geçtiğinden ve o dönemde henüz Uludağ adlandırması olmadığından göstergenin aslına çevirisinde anlatının geçtiği zamana bağlı kalınmadığı söylenebilir. Bunun yanı sıra Şanda, Pardoe'nun mitolojik anlatıların etkisiyle ‘Tanrıların meskeni” olarak ifade ettiği bölümü “Allah'ın mekânı” olarak Türkçeye çevirerek anlamsal açıdan Pardoe'dan farklı bir göstergeye dönüştürmüştür. Dolayısıyla söz konusu göstergelerin aslına çevrilirken dil ve kültür farklılıklarından doğan anlamlandırma sorunuyla sınandıkları söylenebilir. Öte yandan Büyükkal'ın, Pardoe'nun İngiliz okur için çevirdiği söz konusu göstergeleri "Keşiş Dă̆ı” ismini ve “Tanrıların dağı” tabirini kullanarak tekrar çıkış kültürüne çevirdiği ifade edilebilir.

\section{Örnek 2.}

Pardoe'nun İstanbul ziyareti sırasında Osmanlı İmparatorluğu pek çok farklı din, dil ve mezhepten insana ev sahipliği yapmaktadır. Özellikle Rumların ağırlıklı olduğu ilçeler bulunmakta, Pardoe da buralara sıklıkla ziyaretler gerçekleştirmektedir. Bir Rum evinde baloya katılacak olan Pardoe, baloya "Kachishesh Oglou" isimli birinin ev sahipliği edeceğini söyler ve bu ismin anlamın "son of the Hermit" olarak okuyucuya açıklar.

Tablo 3. Lakapların aktarımı

\begin{tabular}{|l|l|l|}
\hline İnceleme Metinleri & İncelenen Bağlam & Çözümleme Öğeleri \\
\hline Pardoe, 1845, cilt 1:52 & $\begin{array}{l}\text { The house of the Merchant by whom the ball was to be } \\
\text { given, and whose name was Kachishesh Oglou, signifying } \\
\text { "son of the Hermit”, was next door to that in which we were } \\
\text { already guests... }\end{array}$ & $\begin{array}{l}\text { Kachishesh Oglou, } \\
\text { signifying "son of the } \\
\text { Hermit” }\end{array}$ \\
\hline Pardoe, 1967 & -- & - \\
\hline Pardoe, 2017, 57 & $\begin{array}{l}\text { Baloyu verecek olan "Keşişoğlu” adlı tacirin evi, misafir } \\
\text { olduğumuz eve komșuydu... }\end{array}$ & "Keşişoğlu” \\
\hline
\end{tabular}
Osmanağa Mahallesi, Mürver Çiçeği Sokak, No:14/8 Kadıköy - İSTANBUL / TÜRKIYE 34714 e-posta: editor@rumelide.com tel: +90 $5057958124,+902167730616$
Address

RumeliDE Journal of Language and Literature Studies

Osmanağa Mahallesi, Mürver Çiçeği Sokak, No:14/8

Kadıköy - ISTANBUL / TURKEY 34714

e-mail: editor@rumelide.com,

phone: +90 505 7958124, +90 2167730616 
The transfer of the urban signs in The City of the Sultan and Domestic Manners of the Turks in 1836 as an example of watermark translation and in its retro-translations / S. Öztürk Kasar; K. Çelik (pp. 1067-1084)

"Hermit” sözcüğünün Türkçe anlamları incelendiğinde "Münzevi”, "İnzivaya çekilmiş kişi”5 olarak tanımlandığı görülmektedir. Pardoe'nun lakabı aktarım şekli incelendiğinde "Keşiş" sözcüğünü açımladığı görülür. Pardoe "Keşişoğlu” lakabını duyduğu şekliyle ve İngilizce sesletimiyle İngiliz okura aktarır. Okur için okuma kolaylığı sağlayabilecek bu uygulamayı, lakabın anlamını da açılamasıyla sürdürerek gerçek anlamda bir çeviri sunar. Pardoe'nun yaptığı zihinsel çeviri işlemi “ kâğıt paraların dokusundaki filigran gibi metnin dokusunda bir iz” ( Öztürk Kasar, 2020, 3) bırakmıştır. Dolayısıyla söz konusu özde çeviri okurunun özgün eser değil de bir çeviri eser okuyormuş düşüncesine kolaylıkla kapılabileceği söylenebilir.

Öte yandan aslına çeviri metinler incelendiğinde Şanda'nın özgün metnin kısaltılmış bir çevirisini sunması nedeniyle söz konusu göstergenin çeviri metinden tümüyle çıkarıldı̆̆ görülmüştür. Dolayısıyla bu bölümdeki Pardoe'ya ait özde çeviri izleri aslına çeviride yer almamaktadır. Diğer aslına çeviri metin olan Büyükkal'ın çevirisinde ise Pardoe'nun İngilizce sesletim ile kaleme aldığı "Keşişoğlu" lakabı sesletimiyle aktarılmış ve Türk okurun aşina olduğu bir ifade olduğu için Pardoe'nun lakabı tanımladığı ifadeler aslına çeviri metne eklenmemiştir. Dolayısıyla özde çeviri metni çıkış dil ve kültürüne taşıyan çevirmenin Türkçeye, Türk kültürüne hakimiyetinin metin içinde tekrardan kaçınmasına katkı sağladığı söylenebilir.

\subsection{Tarihi göstergelerin aktarımı}

Çalışmamızın bütüncesini oluşturan seyahatname 19. yy. Osmanlı topraklarında bulunan tarihi yapılardan, önemli tarihi figürlere çok sayıda tarihi göstergeyle örülüdür. Çalışmanın bu bölümünde Pardoe'nun özde çeviri eserinde yer verdiği tarihi anıt ve şahsiyetler ile bu tarihi göstergelerin aslına çeviri eserlerde ne şekilde aktarıldığı irdelenecektir.

\section{Örnek 3.}

Pardoe'nun seyahat ettiği gemi, 30 Aralık 1835’te karlı bir İstanbul'a demir atar. Bakışlarını merakla kıyıda gezdiren Pardoe, İstanbul'u kaplayan tarihi ve doğal güzellikleri büyük bir hayranlıkla gözlemler ve eserinde bu gözlemlere dair betimlemeler sunar. Așağıdaki örnek tam da bu zamanları, Pardoe'nun İstanbul'la ilk karşılaşma anlarını yansıtır. Karlar altındaki İstanbul'a bakarken Pardoe'nun gözleri çok merak duyduğu Ayasofya ve Süleymaniye camilerini arar ve Pardoe, İstanbul'un önemli tarihi yapılarından olan bu iki cami'nin adını İngiliz okura aşina gelebilecek bir şekilde nakletmeye gayret gösterir.

Tablo 4. Tarihi anitların aktarımı

\begin{tabular}{|l|l|l|}
\hline İnceleme Metinleri & İncelenen Bağlam & Çözümleme Öğeleri \\
\hline $\begin{array}{l}\text { Pardoe, 1845, cilt } \\
\mathbf{1 : 2}\end{array}$ & $\begin{array}{l}\text { Eagerly did I seek to distinguish those of St. Sophia } \\
\text { and the smaller but far more elegant Solimanié, the } \\
\text { shrine of the Prophet's Beard... }\end{array}$ & $\begin{array}{l}\text { St. Sophia } \\
\text { Solimanié, the shrine of the } \\
\text { Prophet's Beard }\end{array}$ \\
\hline Pardoe, 1967, 20 & $\begin{array}{l}\text { Sabırsılıkla, Ayasofya' yı ve ondan daha küçük, fakat } \\
\text { daha zarif olan dört minareli ve avluları kemerli } \\
\text { Süleymaniye'yi, fark etmeye çalıștım. }\end{array}$ & $\begin{array}{l}\text { Ayasofya } \\
\text { Süleymaniye }\end{array}$ \\
\hline Pardoe, 2017, 4 & $\begin{array}{l}\text { Merakla Ayasofya'yı ve dört minaresiyle, revaklı } \\
\text { avlularıla daha küçük ama çok daha zarif } \\
\text { Süleymaniye'yi (Peygamber'in Sakalı'nın [Sakal-ı Şerif }\end{array}$ & $\begin{array}{l}\text { Ayasofya } \\
\text { Süleymaniye'yi (Peygamberin } \\
\text { Sakalınnn [Sakal-1 Şerif] }\end{array}$ \\
\hline
\end{tabular}

5 Cambridge Online Sözlük. https://dictionary.cambridge.org/tr/s\%C3\%B6zl\%C3\%BCk/ingilizcet\%C3\%BCrk\%C3\%A7e/hermit. [08.02.2021]

RumeliDE Dil ve Edebiyat Araşttrmaları Dergisi Osmanağa Mahallesi, Mürver Ciçeği Sokak, No:14/8 Kadıköy - İSTANBUL / TÜRKIYY 34714 e-posta: editor@rumelide.com tel: +90 505 7958124, +90 2167730616 
Bir kathedral olarak inşa edilen ve Saint Sophia ya da Hagia Sophia olarak bilinen yapı, Osmanlı'nın 1453 yllında İstanbul'u fethetmesiyle Cami-i Ayasofya-i Kebir adını alarak camiye dönüştürülür (İkinci, 2014,35). Pardoe'nun temelleri Bizans dönemine dayanan bu tarihi yapıyı İngiliz okurun bildiği ismiyle "St. Sophia" olarak aktarmasıyla söz konusu göstergeyi zihinsel bir çeviri işlemine tabi tuttuğu söylenebilir. Her iki aslına çeviri eser incelendiğinde ise başlangıçta Cami-i Ayasofya-i Kebir olarak adlandırılan ancak halk arasında Ayasofya cami olarak anılan yapının bu isimle çevrildiği görülür. Dolayısıyla çevirmenler Şanda ve Büyükkal'ın söz konusu göstergeyi Türk okur tarafından bilinen isme dönüștürerek bir aslına çeviri örneği sundukları söylenebilir.

Pardoe'nun söz ettiği bir diğer önemli tarihi yapı ise Süleymaniye camidir. Pardoe, caminin ismini kulağının işittiği bir biçimde, İngilizce sesletimiyle okura aktarmış bir nevi İngilizceleștirmiştir. Bu tercih ile amacının okurun daha kolay ve özgüne yakın bir okuma gerçekleștirmesi olduğu düşünülebilir. Ancak Pardoe, yalnızca özel bir adı çevirmek ile kalmamış, bu yapıya uzak olan okuru bilgilendirmek amacıyla yapıya özgü diğer bir özelliğe de yer vererek buranın Hz. Muhammed’in sakal kıllarının muhafaza edildiği bir ibadethane olduğunu belirtmiştir. Dolayısıyla Pardoe'nun kendisi için erek olan bir kültürden kaynak kültürüne yaptığı aktarımda hem özel bir ismi çevirmesi hem de bu ismi bilmeyen okura ek bilgi sunması yapılan zihinsel çeviri işleminin, dolayısıyla eserin bir özde çeviri olduğunun göstergesidir. Nitekim "özde çeviri eğretilemeli bir edim değildir; özde çeviride gerçek anlamda ama çok özel türde bir çeviri işlemi söz konusudur” ( Öztürk Kasar, 2020, 21).

Aslına çeviri eserler incelendiğindeyse çevirmen Şanda, "Solimanie" olarak İngilizceleştirilen ismi "Süleymaniye" şeklinde aslına çevirmiş ve Pardoe tarafından eklenen bilgiye çevirisinde yer vermemiştir. Ek bilgiye yer verilmemesinin nedeni Türk okurun Süleymaniye camine yabancı olmamasından kaynaklanabileceği gibi günümüzde Sakal-ı Şerif in yalnızca Süleymaniye camide değil Türkiye'de yer alan pek çok farklı müze ya da camide yer almasından kaynaklanıyor olabilir. Nitekim 422 tanesi İstanbul'da olmak üzere Türkiye'de 1818 adet sakal-ı şerif bulunmaktadır' ${ }^{6}$.

Öte yandan Büyükkal'ın çevirisi incelendiğinde Şanda'dan farklı bir yol izlenerek Pardoe'nun İngiliz okura aktardığı bilgi hem İslami literatürde anıldığı üzere "Sakal-ı Şerif" olarak hem de Pardoe'nun özde çevirisinin doğrudan çevirisi “Peygamberin Sakalı” olarak aktarıldığı görülmüş̧ür. Büyükkal'ın bu tercihlerinde söz konusu göstergeyi aslına çevirirken Pardoe'nun özde çevirisinin izlerini Türk okura aktarmak istediği düşünülebilir. Başka bir bakış açısıyla ise bu tercihin Sakal-ı Şerifin bazı Türk okur tarafından anlaşılamayabilecek olmasından ileri geldiği söylenebilir. Sonuç olarak, özde çevirmen Pardoe ve eseri aslına çeviren Şanda ile Büyükkal'ın aynı gösterge üzerindeki farklı uygulamaları çeviri tercihlerini şekillendirmede çevirmenin algı dünyasının etkilerini yansıtmaktadır.

\section{Örnek 4.}

Pardoe, İstanbul ziyaretinde Mihrimah Sultan’ın düğün alayına katılma firsatını da elde eder ve burada yaşanan şaşalı hazırlıkları oldukça ayrıntılı bir şekilde tasvir eder. Bu örnek, İmparatorluktaki dügün adetlerinden birini yansıtır; damadın vekili olarak Serasker, hanım sultanın vekili olarak ise Kızlarağası arasında geçen hediyeleșme merasiminden bir kesit sunar.

İslam Ansiklopedisi. https://islamansiklopedisi.org.tr/sakal-i-serif. [08.02.2021]

\section{Adres Address}

RumeliDE Dil ve Edebiyat Araşttrmaları Dergisi $\quad$ RumeliDE Journal of Language and Literature Studies

Osmanağa Mahallesi, Mürver Çiçeği Sokak, No:14/8 Osmanağa Mahallesi, Mürver Çiçeği Sokak, No:14/8

Kadıköy - İSTANBUL / TÜRKIYE 34714 Kadıköy - ISTANBUL / TURKEY 34714

e-posta: editor@rumelide.com

e-mail: editor@rumelide.com

tel: +90 $5057958124,+90216773$ o 616 phone: +90 505 7958124, +90 216773 o 616 
The transfer of the urban signs in The City of the Sultan and Domestic Manners of the Turks in 1836 as an example of watermark translation and in its retro-translations / S. Öztürk Kasar; K. Çelik (pp. 1067-1084)

Tablo 5. Tarihi şahsiyetlerin aktarımı

\begin{tabular}{|c|c|c|}
\hline İnceleme Metinleri & İncelenen Bağlam & Çözümleme Öğeleri \\
\hline Pardoe, 1845 , cilt 1:199 & $\begin{array}{l}\text {... as he besought the monstrous respresentative of youth and } \\
\text { beauty to have mercy upon the slave who kissed the dust } \\
\text { before the Light of the Creation, the Glory of the Moon* } \\
\text { *Mihirmah, the glory of the moon. }\end{array}$ & $\begin{array}{l}\text { The Light of the } \\
\text { Creation, the Glory of } \\
\text { the Moon* } \\
\text { * Mihirmah, the glory } \\
\text { of the moon. }\end{array}$ \\
\hline Pardoe, 1967,81 & $\begin{array}{l}\text { Gençlik ve güzellik ( Allah’ın Nuru Mihrimah Sultan’ın) } \\
\text { sembolinin önünde tozları öperek lütuf ve merhamet } \\
\text { niyazında bulundu. }\end{array}$ & $\begin{array}{l}\text { Allah'ın Nuru } \\
\text { Mihrimah Sultan }\end{array}$ \\
\hline Pardoe, 2017, 190 & $\begin{array}{l}\text {... gençlik ve güzelliğin bu canavarsı temsilcisinden, } \\
\text { "Yaradan'ın Nuru” ve "Parlayan Ay” Sultan'ın ayağının } \\
\text { altındaki tozu öpen kölesine merhamet etmesini istemiş. }\end{array}$ & $\begin{array}{l}\text { Yaradan'in Nuru ve } \\
\text { Parlayan Ay Sultan }\end{array}$ \\
\hline
\end{tabular}

Pardoe, bu bölümde Mihrimah Sultan’ın adını doğrudan yazmak yerine Farsça kökenli bu ismin kelime anlamını şairane bir biçimde sunmuştur. Çeşitli kaynaklarda "Mihrümah", "Mihrmah" gibi farklı yazımları sunulan bu ismin kelime anlamı "güneş ve ay" olarak bilinmektedir (Eynallı, 2014, 13). Pardoe, Sultan’ın ismini "Evrenin Ișığı”, "Ayın Nuru” 7ifadeleriyle aktarır ve bir dipnot ile burada belirtilenin Mihrimah Sultan olduğunu ismin anlamını yineleyerek ifade eder. Tarihi belgelerde ismin farklı yazımları olsa da Pardoe, bu ismi daha farklı bir biçimde, kendi çevirisiyle "Mihirmah" olarak okuyucuya sunar. Bunun yanı sıra adeta bir çevirmen rolü üstlenerek dipnot ile Farsça kökenli bu ismin anlamını da İngiliz okura aktarır. Pardoe'nun bu seçimi onun "düz anlamda bir çevirmen”, bir “özde çevirmen” ( Öztürk Kasar, 2020, 21) olduğunu da kanıtlar niteliktedir.

Eserin Türkçe çevirileri incelendiğinde öncelikle her iki çeviride de Pardoe'nun "Mihirmah" olarak aktardığı isim Türkçede yerleșik kullanımıyla "Mihrimah" olarak aktarılmıştır. Bunun dışında her iki çeviride farklı stratejiler izlendiği dikkat çekmektedir. Şanda, Pardoe'nun aksine Mihrimah Sultan’ın adını metin içerisinde vermeyi tercih etmiş ve Pardoe'nun ismin "Güneş ve Ay" anlamını yansıtmak için sunduğu ifadeleri "Allah’ın Nuru” olarak Türk okura aktarmıştır. Bu çeviri tercihinin özde çeviride sunulmak istenen ismin "güneş" anlamını içermediği söylenebilir. Bunun yanı sıra "the glory of the moon” göstergesi ise metinden tümüyle silinmiştir. Dolayısıyla özde çeviri izlerinin aslına çeviri metinde yer almadığı ifade edilebilir. Öte yandan Büyükkal’ın çevirisi incelendiğinde Şanda'da olduğu gibi "yaratılış", "kâinatın yaratılıșı"8 anlamına gelen "creation" sözcügünün "Yaradan" anlamında kullanıldığı görülür. Büyükkal " the glory of the moon" ifadesini "Parlayan Ay" olarak çevirerek ismin içerdiği "Ay" anlamını okura aktarsa da "Yaradan" sözcügünün tercihiyle "Güneş" anlamının aktarılamadığı söylenebilir. Bunun yanı sıra Büyükkal, bu sözcüklerle ifade edilenin Mihrimah Sultan olduğuna çevirisinde yer vermemiş ve yazar tarafından dipnot ile açıkça belirtilen bu göstergeyi gizlemiştir. Dolayısıyla çevirmenlerin bu uygulamaları, farklı kavram dünyaları arasındaki izleri içeren özde çeviri metin aslına çevrilirken bazı anlamlandırma sorunlarını da beraberinde getirebileceğinin göstergesi olarak düşünülebilir.

\subsection{Kültürel göstergelerin aktarımı}

Pardoe'nun eserinde konu edindiği coğrafya farklı din, dil ve mezhepten çok sayıda kişiyi barındıran büyük bir imparatorluk toprağıdır. Farklı kültürlerin kaynaștığı bu topraklar bize kültürel göstergeler açısından da zengin bir evren sunmaktadır. Bu bölümde Osmanlı topraklarındaki günlük

Çeviri tarafimızca yapılmıştır.

Cambridge Online Sözlük. https://dictionary.cambridge.org/dictionary/english/creation. [10.02.2021]

Adres $\mid$ Address

RumeliDE Dil ve Edebiyat Araştırmalar Dergisi $\quad$ RumeliDE Journal of Language and Literature Studies Osmanağa Mahallesi, Mürver Çiçeği Sokak, No:14/8 Osmanağa Mahallesi, Mürver Çiçeği Sokak, No:14/8

Kadıköy - İSTANBUL / TÜRKIYE 34714 Kadıköy - ISTANBUL / TURKEY 34714 e-posta: editor@rumelide.com e-mail: editor@rumelide.com,

tel: +90 505 7958124, +90 2167730616 phone: +90 505 7958124, +90 2167730616 
alışkanlıklardan dini göstergelere, yemek kültüründen giyime, deyişlerden müzik aletlerine kültürel evreni yansıtan çok sayıdaki göstergeye yer verilmeye çalışılmıştır.

\section{Örnek 5.}

Bu örnek, Pardoe'nun Osmanlı topraklarındaki ilk hamam ziyaretine ilişkin gözlemlerini aktardığı bölümden alınmıştır. Pardoe, Batı için büyük merak konusu olan Doğu'nun hamamlarını en ince ayrıntısıyla anlatma gayesiyle her bölümünü Batılı okurun zihninde canlandırabileceği şekilde çevirmeye gayret göstermiştir. Dolayısıyla hamama özgü bölümleri adlandırıldıkları biçimde değil işlev ya da konumuna göre zihinsel bir çeviri işlemine tabi tutup aktardı̆̆ı söylenebilir. Nitekim bu örnekte de hamamın hemen girişinde yer alan camekândan, ikinci bölüm olan llıklık ya da başka bir ifadeyle soğukluk bölümüne geçişini anlatmaktadır.

Tablo 6. Toplumsal yaşam ve günlük alışkanlıkların aktarımı

\begin{tabular}{|l|l|l|}
\hline İnceleme Metinleri & İncelenen Bağlam & Çözümleme Öğeleri \\
\hline Pardoe, 1845, cilt 1:96 & ... on crossing the threshold, found myself in the cooling room... & The cooling room \\
\hline Pardoe, 1967, 55 & Eşiği geçer geçmez, serinleme yerine girdim. & Serinleme yerine \\
\hline Pardoe, 2017, 103 & $\begin{array}{l}\text { Eşiği geçer geçmez kendimi serinleme odasında, yani soğuklukta } \\
\text { buldum. }\end{array}$ & $\begin{array}{l}\text { Serinleme odasında, } \\
\text { yani soğuklukta }\end{array}$ \\
\hline
\end{tabular}

Ertuğrul (2009, 241), hamam mimarisi üzerine yaptığı çalışmasında ılıklık başlığıyla andığı hamamın bu ikinci bölümünü "Hamamlarda sıcaklık bölümüyle soyunmalık arasında yer alan ılık bir geçiş mekânıdır. Bazı kaynaklar da soğukluk diye de adlandırıldığı görülür.” şeklinde tanımlamaktadır. Ertuğrul (2009)'un da ifade ettiği üzere aslında bu bölüm girişte daha yüksek ısıya sahip sıcaklık bölümüne, çıkıșta ise daha düşük sıcaklığa sahip camekâna hazırlayan bir geçiş bölümüdür. Eserinde bu bölümün sıcaklıkla arasındaki ısı farkını da detaylarıyla işleyen Pardoe,'nun, söz konusu bölümü "the cooling room" olarak yabancı okura aktarması eserin özde çeviri oluşunu destekler niteliktedir.

Aslına çeviri metinlere bakıldığındaysa çevirmen Bedriye Şanda "serinleme yeri" şeklinde bir çeviri sunarak Osmanlı hamamlarının geleneksel mimari özelliklerinden biri olan ve soğukluk olarak adlandırılan bu bölümü Türkçe literatürde yer alan şekilde çevirmektense Pardoe'nun yabancı okur için anlamını açı etmeye çalıştığı biçimde doğrudan çevirmeyi tercih etmiştir. Büyükkal ise daha farklı bir strateji izlemiş, hem hamam literatüründe bu bölüm için kullanılan "soğukluk" sözcüğünü hem de Pardoe'nun ifadelerini doğrudan çevirmeyi tercih etmiștir. Büyükkal'ın çoğu Türk okurun hamam terminolojisine hâkim olmaması kaygısıyla böyle bir çeviri sunmuş olabileceği düşünülse de "soğukluk" sözcüğünün hamam kültürüne sahip olmayan bir kiși tarafınca dahi anlaşllabilir olması nedeniyle bu uygulamanın metin içinde tekrara neden olduğu söylenebilir.

\section{Örnek 6.}

Bu örnekte Pardoe, 180o'lü yıllarda Frenk mahallesi olarak bilinen Pera'ya gezintiye çıkar. Oraya vardığında tüm dükkânların kapalı olduğunu görür. Bunun nedenini ise ziyareti gerçekleştirdiği günün Müslümanlar tarafından mübarek addedilen Cuma gününe, hatta Ramazan ayının bir cumasına denk gelmesi olarak açıklar. Pardoe, Cuma gününün Osmanlı halkı için taşıdığı önemi ifade etmek adına bu kültüre yabancı okurun kendi kavram dünyasında yer aldığı düşünülen "Sabbath" göstergesine yer verir.

\footnotetext{
Adres | Address

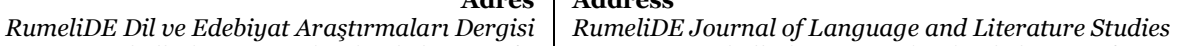
Osmanağa Mahallesi, Mürver Çiçeği Sokak, No:14/8 Osmanağa Mahallesi, Mürver Çiçeği Sokak, No:14/8 Kadıköy - İSTANBUL / TÜRKIYE 34714 Kadıköy - ISTANBUL / TURKEY 34714 e-posta: editor@rumelide.com e-mail: editor@rumelide.com, tel: +90 505 7958124, +90 2167730616 phone: +90 505 7958124, +90 2167730616
} 
The transfer of the urban signs in The City of the Sultan and Domestic Manners of the Turks in 1836 as an example of watermark translation and in its retro-translations / S. Öztürk Kasar; K. Çelik (pp. 1067-1084)

Tablo 7. Dini göstergelerin aktarımı

\begin{tabular}{|l|l|l|}
\hline İnceleme Metinleri & İncelenen Bağlam & Çözümleme Öğeleri \\
\hline $\begin{array}{l}\text { Pardoe, 1845, cilt } \\
\text { 1:9 }\end{array}$ & $\begin{array}{l}\text { And it was Friday, the Turkish Sabbath, and moreover, a } \\
\text { Friday of the Ramazan... }\end{array}$ & $\begin{array}{l}\text { Friday, The Turkish } \\
\text { Sabbath }\end{array}$ \\
\hline Pardoe, 1967, 23 & $\begin{array}{l}\text { O gün, Türklerin kutsal günü olan cuma, fazla olarak da } \\
\text { ramazan ayı içindeki cuma olduğu için... }\end{array}$ & $\begin{array}{l}\text { Türklerin kutsal günü olan } \\
\text { cuma }\end{array}$ \\
\hline Pardoe, 2017, 17 & $\begin{array}{l}\text { Türklerin dini tatil günü cuma, dahası Ramazan ayının bir } \\
\text { cuması olduğu için... }\end{array}$ & $\begin{array}{l}\text { Türklerin dini tatil günü } \\
\text { cuma }\end{array}$ \\
\hline
\end{tabular}

Türkçede Şabat veya Sebt olarak anılan "the Sabbath" sözcügünün tanımına baktığımızda "Bazı dini grupların haftanın belli bir günü ibadet edip dinlendiği gün”9 şeklinde tanımlandığı görülür. Şabat, Yahudiler için Cuma gün batımından Cumartesi gün batımına kadar süren haftalık tatil gününü ifade eder. ${ }^{10}$ Pardoe, Doğu coğrafyasında kutsal sayılan Cuma gününü açıklamak için, Batıda kutsal bir günü ifade eden "Sabbath" sözcüğün̈ kullanarak bir tür özde çeviri gerçekleștirmiștir.

Aslına çeviri metinler incelendiğinde ise çevirmen Bedriye Şanda'nın Cuma günü için yazarın kullandığı açıklama içeren sözcükleri de çevirmeyi tercih ettiği ve bu bölümü okuyucuya "Türklerin kutsal günü” olarak aktardığı görülür. Şanda’nın bu tercihiyle hem özde çevirmenin okura sunduğu yeni bilgiyi Türkçedeki bağlamına uygun bir şekilde aslına çevirdiği hem de özde çevirinin izini koruduğu söylenebilir.

Çevirmen Banu Büyükkal ise söz konusu ifadeyi "Türklerin dini tatil günü” olarak açlklamıştır. Türkçeye Arapçadan geçen ve kelime anlamı olarak "sakin olma, dinlenme, ara verme" "1'yi ifade eden "sebt" sözcüğü, Yahudilerde tam bir kapanma, dinlenme ve ibadet için ayrılan bir tatil gününü ifade etmektedir. Türklerde Cuma günü günümüzde bu şekilde bir tatil gününü ifade etmese de Türkiye'de 1935 yılına kadar hafta tatili Cuma günü uygulanmıștır (Deniz,2011,65). Dolayısıyla özde çeviri eserin kaleme alındığı yllarda Cuma günü Osmanlı İmparatorluğu'nda bir tatil günüdür. Büyükkal'ın bu çeviri tercihiyle bütüncenin yazıldığı tarihi dikkate aldığı ve bunun bir "dini" tatil günü olduğunu da belirterek bu uygulamanın dinsel kaynaklı olduğunu vurguladığı düşünülmektedir. Çevirmen bu tutumuyla, yazarın özde çeviri izlerini koruyarak bir aslına çeviri örneği sergilemiştir.

\section{Örnek 7.}

Pardoe, İstanbul'a ayak bastığı gün Ramazan ayının bir gününe denk gelmektedir ve bu topraklarda yaşamak istediği ilk deneyim bir Türk ailesinin evinde oruçlu bir gün geçirmektir. Nitekim ona tercümanlık yapacak Rum arkadaşıyla birlikte itibarlı bir Türk tüccarın evine davet edilmesiyle bu isteği gerçekleşmiş olur. Pardoe, bu davette yaptığı gözlemler ile iftar sofrasında Türklerin yedikleri yiyeceklerden, nasıl yemek yediklerine değin pek çok detaya yer verir. Pardoe'nun iftar sofrasında dikkatini çeken yiyeceklerden biri Türklerin önemli Ramazan geleneklerinden biri olan Ramazan pidesidir.

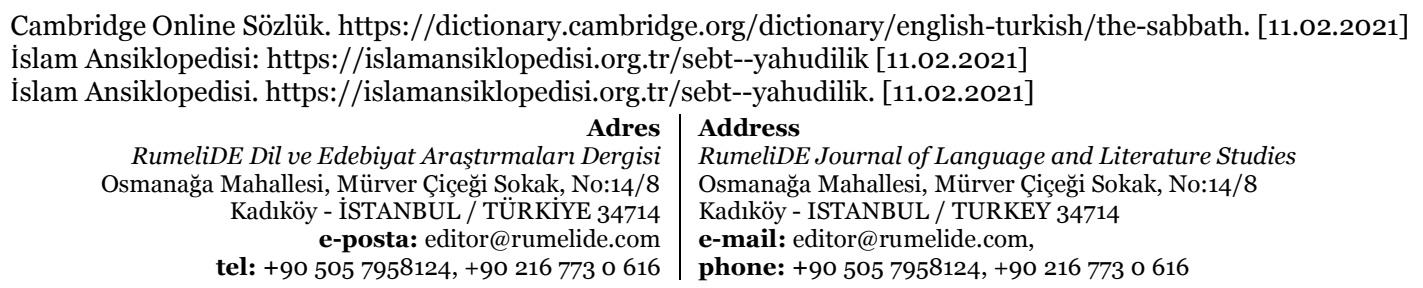


Tablo 8. Yemek kültürünün aktarımı

\begin{tabular}{|c|c|c|}
\hline İnceleme Metinleri & İncelenen Bağlam & $\begin{array}{l}\text { Çözümleme } \\
\text { Ögeleri }\end{array}$ \\
\hline Pardoe, 1845 , cilt 1:15 & $\begin{array}{l}\text {... and portions of the Ramazan cake, a dry, close, sickly kind of } \\
\text { paste, glazed with the whites of eggs, and strewed over with aniseeds. }\end{array}$ & $\begin{array}{l}\text { The Ramazan } \\
\text { cake }\end{array}$ \\
\hline Pardoe, 1967, 29 & $\begin{array}{l}\text {... sert, kalın ve hiç de hoşuma gitmeyen bir hamurdan yapılmış } \\
\text { ramazan ekmeği (ramazan pidesi olacak) konulmuştu. Bu pidenin } \\
\text { üzerine, yumurta akı sürülmüş ve çöreotu serpilmişti Bunlar da } \\
\text { küçük parçalara bölünmüştü. }\end{array}$ & $\begin{array}{l}\text { Ramazan ekmeği } \\
\text { (ramazan pidesi } \\
\text { olacak) }\end{array}$ \\
\hline Pardoe, 2017, 20 & $\begin{array}{l}\text {... kuru/ berbat görünümlü, üstü yumurta akıyla parlatılmış ve } \\
\text { çörekotu serpilmiş Ramazan pidesi duruyordu. }\end{array}$ & Ramazan pidesi \\
\hline
\end{tabular}

Pardoe, Türk mutfağına özgü bu yiyeceği İngiliz okura anlatırken görüntüsünü detaylı bir şekilde tasvir etmenin yanı sıra adını da "the Ramazan cake" olarak çevirmeyi tercih eder. İngiliz mutfağında bulunmayan "pide", Pardoe tarafindan muhtemelen "çörek" anlamıyla "cake" olarak metinde yerini alır. Türk mutfağına özgü bu yiyeceğin detaylı bir şekilde tasvir edilmesinin yanı sıra Türkçe "Ramazan" isminin korunarak İngiliz mutfağındaki benzer bir yiyeceğin adıyla karşılanması Pardoe'nun zihninde gerçekleşen çeviri işleminin bir göstergesi olmakla beraber eserin özde çeviri niteliğini de gözler önüne serer.

Aslına çeviri eserler incelendiğinde çevirmenler Bedriye Şanda ve Banu Büyükkal'ın farklı stratejiler izlediği görülür. Şanda, özgün eserdeki çeviri işlemini erek metinde de korumak istercesine söz konusu yiyeceği Türkçede bulunmayan bir tabir ile "Ramazan ekmeği" olarak çevirmiş, ancak parantez içinde kendi çevirisini düzelten "ramazan pidesi olacak" şeklinde bir dipnot ekleyerek eserin aslına çeviri oluşunu desteklemiştir. Büyükkal ise Pardoe'nun İngiliz okur için çevirdiği bu geleneksel Ramazan yiyeceğini Türk okurun aşina olduğu şekilde "Ramazan pidesi” olarak çevirerek aslına döndürmüştür.

\section{Örnek 8.}

Pardoe'nun İstanbul seyahatinde görme firsatı bulduğu yerlerden biri de Galata Mevlevihanesi'dir. Pardoe Mevlevihane'yi iki defa ziyaret eder ve sema ayinlerinden tekkenin mimarisine dek her şeyi ayrıntılı bir biçimde tasvir etmeye çalışır. Mevlevihane'nin girişinde karşılaştığı türbedeki sandukalar Pardoe'nun dikkatini çeker. Pardoe, sandukaları betimlerken her birinin başında yer alan Mevlevi külahlarından söz eder.

Tablo 9. Aksesuarların aktarımı

\begin{tabular}{|l|l|l|}
\hline İnceleme Metinleri & İncelenen Bağlam & Çözümleme Öğeleri \\
\hline Pardoe, 1845, cilt 1:28 & $\begin{array}{l}\text {...at the head of each tomb is placed the geulaf, or } \\
\text { Dervishes' hat... }\end{array}$ & The geulaf, or Dervishes' hat \\
\hline Pardoe, 1967, 44 & Her sandığın başına da bir kavuk konmuştur. & kavuk \\
\hline Pardoe, 2017, 37 & ...her mezarın baş tarafına birer külah yerleștirilmiş... & külah \\
\hline
\end{tabular}

Mevlevilere özgü başlığı Pardoe, İngilizce sesletimle "geulaf" olarak İngiliz okura aktarır. Ancak "geulaf” sözcüğü İngiliz okur’un kavram dünyasında bulunmadığından bunun bir tür başlık olduğunu “Dervishes' hat” açıklamasıyla ifade eder. Dolayısıyla Pardoe'nun bu sözcüğü hem işitsel hem de anlamsal olarak İngiliz okurun anlayabileceği şekilde ifade etmesiyle bir özde çeviri örneği sergilediği söylenebilir.

\begin{tabular}{|c|c|}
\hline es & \\
\hline RumeliDE D & dLiterature Studies \\
\hline a Mah & Mahallesi, Mürver Çiçeği Sokak, No:14/8 \\
\hline Kadıköy - İSTANBUL / & ISTANBUL / TURKEY 34714 \\
\hline $\begin{array}{l}\text { e-posta: editor@rumelide. } \\
\text { tel: }+905057958124,+902167730\end{array}$ & $\begin{array}{l}\text { editor@rumelide.com, } \\
\text { +90 505 7958124, +90 } 216773 \text { o } 616\end{array}$ \\
\hline
\end{tabular}


The transfer of the urban signs in The City of the Sultan and Domestic Manners of the Turks in 1836 as an example of watermark translation and in its retro-translations / S. Öztürk Kasar; K. Çelik (pp. 1067-1084)

Aslına çeviriler incelendiğinde Şanda'nın aslında Türkçe bir sözcüğün İngilizce sesletimi olan 'geulaf' sözcügünü Osmanlı İmparatorluğu’nda kullanılan başlı türlerinden biri olan "kavuk” olarak çevirdiği görülür. Küçükkaya (2019, 27), Galata Mevlevihanesi'ndeki mezar taşlarını incelediği çalışmasında mezar taşlarının fotoğraflarına yer verir ve “...Mevlevi olduğu başındaki sikkeden belli...” ifadeleriyle dervişlerin giydiği başlığın "sikke" olarak adlandırıldığını görsellerle destekleyerek ortaya koyar. "Sikke" sözcüğünün tanımına bakıldığında "Mevlevi dervişlerinin giydikleri yüksek ve tepesi düz keçe külah"12 olarak ifade edildiği görülmektedir. Dolayısıyla "geulaf" göstergesinin çıkış kültüründeki farklı bir başlık türü olan "kavuk" olarak aktarılmasıyla aslına çeviride dönüştüğü söylenebilir. Öte yandan Büyükkal'ın çevirisi incelendiğinde her ne kadar Mevlevi dervişlerinin kullandığı başlıklar için "sikke" kullanımı yaygın olarak tercih edilse de "külah" tercihiyle yazarın özde çeviri işlemini aslına çevirdiği söylenebilir. Bunun yanı sıra her iki aslına çeviri metinde de "Dervishes' hat" bölümünün çevrilmediği görülmektedir. Türk okurun aşina olduğu bu aksesuara ilişkin açıklamanın çevrilmeden bırakılması aslına yapılan çeviride çevirmen kararının açık bir göstergesidir.

\section{Örnek 9.}

Pardoe için İstanbul topraklarında şahit olduğu en ilginç konulardan biri de Osmanlı toplumunun batıl inançlarıdır. Pek çok farklı ortamda bulunan Pardoe, toplumun farklı kesimlerinden insanların ne gibi batıl itikatları olduğunu gözlemleme firsatı edinmiștir. Bu örnekte de Osmanlı topraklarında en yaygın batıl inancın nazardan duyulan korku olduğunu ifade etmekte ve bunu "Maşallah" deyişinin kullanımıyla örneklendirmektedir. Şayet bir bebeği severken "Maşallah" deyişi kullanılmaz ve o bebeğe bir zarar gelirse "Maşallah” demeyen kişinin nazar değdirdiğine inanıldığına değinir.

Tablo 1o. Deyişlerin aktarımı

\begin{tabular}{|l|l|l|}
\hline İnceleme Metinleri & İncelenen Bağlam & $\begin{array}{l}\text { Çözümleme } \\
\text { Öğeleri }\end{array}$ \\
\hline Pardoe, 1845, cilt 1: 211 & $\begin{array}{l}\text { Should you praise the beauty of a Turkish child to its mother, } \\
\text { without prefacing your admiration with “Mashallah!” or, In the } \\
\text { name of God--which is considered sufficient to counteract the power } \\
\text { of all malignant spirits... }\end{array}$ & $\begin{array}{l}\text { "Mashallah!” or, } \\
\text { In the name of } \\
\text { God }\end{array}$ \\
\hline Pardoe, 1967, 93 & $\begin{array}{l}\text { Şayet, bir çocuğun güzelliğini, "Maşallah, Allah bağışlasın” demeden } \\
\text { (çünkü bu sözler, bütün kötü ruhların kudretini yok eder) annesine } \\
\text { methedecek olursanız... }\end{array}$ & $\begin{array}{l}\text { "Mâşallah, Allah } \\
\text { bağlasın” }\end{array}$ \\
\hline Pardoe, 2017, 206 & $\begin{array}{l}\text { Annesine bir Türk çocuğunun güzelliğini ilk önce "Maşallah” ( } \\
\text { bunun bütün kötü ruhların gücüne karşı kâfi olduğu kabul ediliyor) } \\
\text { demeden methederseniz... }\end{array}$ & "Mâşallah” \\
\hline
\end{tabular}

Pardoe, Maşallah sözcügünü İngilizce sesletimiyle, “Mashallah” olarak okura sunar. Ancak söz konusu deyiş İngilizce transkripsiyona uygun bir şekilde kaleme alınsa da İngiliz okurun kavram dünyasında olmaması nedeniyle okurun zihninde herhangi bir imge oluşmayabilir. Bu nedenle, Pardoe'nun İngilizce sesletim ile kaleme aldığı bu deyişi açımlama yoluna gittiği ve ona "In the name of god (Allah'ın adıyla)" ${ }^{13}$ şeklinde bir İngilizce karşıllk eklediği görülmektedir. Ancak Arapça kökenli "Mâşallah" deyişinin anlamına baktığımızda "Allah dileyince her şey olur.14" manâsına geldiğini görmekteyiz. Pardoe'nun bu deyişi açımlamak için eklediği ve "Allah'ın adıyla" olarak çevirdiğimiz "In the name of god" ise İslam dininde genellikle bir ișe başlarken söylenen, "Besmele" olarak da anılan "Bismillâhirrahmânirrahîm (Rahmân ve rahîm olan Allah'ın adıyla)" deyișinin adı "Bismillâh (Allah’ın

Türk Dil Kurumu Sözlükleri. https://sozluk.gov.tr/. [ 13.02.2021]

Çeviri tarafimızca yapılmıştır.

İslam Ansiklopedisi: https://islamansiklopedisi.org.tr/masallah. [14.02.2021]

Adres $\mid$ Address

RumeliDE Dil ve Edebiyat Araşttrmaları Dergisi $\quad$ RumeliDE Journal of Language and Literature Studies Osmanağa Mahallesi, Mürver Çiçeği Sokak, No:14/8 Osmanağa Mahallesi, Mürver Çiçeği Sokak, No:14/8 Kadıköy - İSTANBUL / TÜRKIYE 34714 Kadıköy - ISTANBUL / TURKEY 34714 e-posta: editor@rumelide.com e-mail: editor@rumelide.com, tel: +90 505 7958124, +90 216773 o 616 phone: +90 505 7958124, +90 216773 o 616 
adıyla) 15" ile aynı anlamı taşımaktadır. Dolayısıyla Pardoe'nun diller ve kültürlerarası farklılıktan dolayı söylenişleri benzer olan "Mâşallah" ile "Bismillâh" deyişlerini karıştırdığı düşünülmektedir. Yaşanan bu karışıklığın metnin dokusunda Pardoe’nun zihinsel çevirisinin izlerini bıraktığı ve eserin özde çeviri niteliğini desteklediği söylenebilir.

Öte yandan aslına çeviri metinler incelendiğinde Şanda'nın bu deyişi "Mâşallah. Allah bağışlasın” diyerek Türkçeye çevirdiği görülmektedir. Şanda, "Mashallah" göstergesini Türkçe sesletimiyle aktarmış ve Pardoe'nun açımlama yaptığı bölümü "Mâşallah" deyişiyle benzer anlam taşıyan "Allah bağışlasın” sözleriyle aktarmıştır. Dolayısıyla özde çeviride diller ve kültürlerarası farklılıktan kaynaklanan karışıklığın aslına çeviride giderildiği söylenebilir. Büyükkal da Şanda gibi "Mashallah" deyişini Türkçe sesletim ile kaleme almış ancak "In the name of god" ifadesini çevirmemiștir. Daha önce belirtildiği üzere Pardoe’nun, bu ifadeyi "Mâşallah” sözcügünün anlamını okuyucuya iletmek maksadıyla kullandığı düşünülmektedir. Bu deyişin anlamı Türk okur tarafından bilindiğinden Büyükkal'ın aynı anlamda kullanılabilecek diğer bir ifadeyi yinelemekten kaçınmış olabileceği düşünülebilir.

\section{Örnek 10.}

Daha öncede belirttiğimiz gibi Pardoe, babasının itibarlı mesleği sayesinde Osmanlı hanedanını yakından gözlemleme fırsatını elde eder. Aşağıdaki örnek dönemin padişahı II. Mahmut'un ablası Esma Sultan'ın sahil sarayına konuk olduğu bir günden alınmıştır. Pardoe, sarayın hareminde evin kadınlarıyla tanışır ve onların gün içinde neler yaptıklarını gözlemleme fırsatı elde eder. Esma Sultan'ın gözdesi Nazif Hanım bir kâtibenin dairesindeyken orada bulunan hanımlara müzik ziyafeti sunar.

Tablo 11. Enstrümanların aktarımı

\begin{tabular}{|l|l|l|}
\hline İnceleme Metinleri & İncelenen Bağlam & $\begin{array}{l}\text { Çözümleme } \\
\text { Ögeleri }\end{array}$ \\
\hline Pardoe, 1845, cilt 1:226 & $\begin{array}{l}\text {...Nazip Hanoum, at the request of the fair and faded visitor, sent a } \\
\text { slave for her zebec... }\end{array}$ & zebec \\
\hline Pardoe, 1967 & - & - \\
\hline Pardoe, 2017, 215 & $\begin{array}{l}\text {... solgun ziyaretçinin ricası üzerine, Nazif Hanım bir halayı̆ga } \\
\text { kemençesini* getirtti... } \\
\text { *Yazarın zebec olarak aktardı̆̆ı bu çalgı muhtemelen rebec } \\
\text { olmalıdır. Rebec, klasik Türk musikisindeki kemençeyle akraba } \\
\text { olan bir yaylı çalgıdır (ç.n.). }\end{array}$ & kemençe \\
\hline
\end{tabular}

Nazif Hanım’ın çaldığı enstrüman, Pardoe tarafından "zebec" olarak aktarılır. "Zebec" adında bir müzik aleti bulunmaması nedeniyle bu çalgının Ortaçağ dönemi ve Erken Rönesans’a ait yaylı bir çalgı olan rebec ile karıștırılmış olabileceği düşünülmektedir. Rebec, Arapların rebab adlı müzik aletinden geliştirilen ve Müslüman kültürüyle Avrupa'ya taşınan yaylı bir müzik aleti olarak tanımlanmaktadır. ${ }^{16}$ Avrupa'da Ortaçağ ve Rönesans'ı temsil ettiği düşünülen bu müzik aletinin varyasyonlarından biri olan kemençe 18. yy' dan itibaren Osmanlı Türk Musikisinde yaylı çalgı olarak önem kazanmıştır (Çolakoğlu, Eken, 2009, 181). Dolayısıyla Pardoe'nun Osmanlı sarayında çalınan kemençeyi kendi kültüründe anıldığı ismine çevirerek zebek (rebek) olarak aktardığı ve bu çeviri işlemiyle eserin bir özde çeviri oluşunu desteklediği söylenebilir.

15 İslam Ansiklopedisi: https://islamansiklopedisi.org.tr/bismillah. [14.02.2021]

16 Britanicca Ansiklopedisi. https://www.britannica.com/art/rebec. [13.02.2021]

Adres | Address

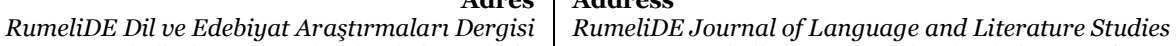

Osmanağa Mahallesi, Mürver Çiçeği Sokak, No:14/8 Osmanağa Mahallesi, Mürver Çiçeği Sokak, No:14/8

Kadıköy - İSTANBUL / TÜRKIYE 34714 Kadıköy - ISTANBUL / TURKEY 34714

e-posta: editor@rumelide.com e-mail: editor@rumelide.com,

tel: +90 505 7958124, +90 2167730616 phone: +90 505 7958124, +90 2167730616 
The transfer of the urban signs in The City of the Sultan and Domestic Manners of the Turks in 1836 as an example of watermark translation and in its retro-translations / S. Öztürk Kasar; K. Çelik (pp. 1067-1084)

Öte yandan aslına çeviri metinler incelendiğinde Şanda’nın çevirisinde söz konusu göstergenin yer aldığı bölüme yer verilmediği dikkat çekmektedir. Şanda, özgün metnin kısaltılmış bir çevirisini sunmuş olması dolayısıyla kaynak metinde yer alan pek çok bölüm çeviri metinde yer almamaktadır. Dolayısıyla bu gösterge çeviri metinde yok edilmiş, Pardoe'nun özde çevirisinin izleri silinmiştir. Büyükkal ise rebec adlı müzik aletini 19. yy. Osmanlı'sında da önem taşıdığı düşünülen "kemençe" olarak aslına çevirmiş ve bir de dipnot ekleyerek özde çevirmenin metindeki izlerini koruma gayreti göstermiştir.

\section{Sonuç}

Kent göstergelerinin betimleyici bir yaklaşımla ele alındığı bu çalışmada, Julia Pardoe'nun The City of the Sultan and Domestic Manners of the Turks in 1836 başlıklı seyahatnamesiyle bir özde çeviri örneği sunduğu söylenebilir. Pardoe'nun özde çeviri eserinde adeta bir okur gibi Osmanlı topraklarını gözlem yoluyla okuduğu, söyleme dönüşen bu gözlemlerini İngiliz okurun anlayabileceği yazılı imgelere dönüștürdügü görülmüsstür. Başka bir deyișle Pardoe, "bir kavram dünyasına ait olan bir olguyu, bir varlığı ya da bir nesneyi başka bir kavram dünyasına" taşımış; "bir kültür-dilden bir başka kültür-dile" ( Öztürk Kasar, 2020, 20-21) aktarım sağlayarak bir özde çeviri örneği ortaya koymuştur.

Öztürk Kasar (2020, 5)'ın tanımıyla "Yabancı bağlamdan öz bağlama giden özde çeviriler” başlığı altında ele alınabilecek söz konusu eserde yer alan kent göstergelerinin aktarımı incelenirken yazarın bazı algılama farklılıklarıyla sınandığı ve bu farklılıkların metinde oluşan izler aracılığıyla okunabileceği görülmüștür. Yazıldığı tarihte Batı için büyük merak konusu olan Osmanlı topraklarını, tarafsız bir biçimde aktarma düsturuyla hareket eden Pardoe, bu topraklara ait gözlemlerini gördüğü ya da işittiği biçimde İngiliz okura aktarmış ve okura yabancı olan bu kavramları açıklama yoluyla tanıtmıştır. Nitekim bu çalışmada örneklendirildiği gibi özde çevirmen kenti temsil eden göstergeleri aktarırken üç farklı tutum sergilemiştir: eğer bu göstergeye ait olarak İngiliz okurun halihazırda bildiği bir tanımlaması yoksa duyduğu şekliyle, transkripsiyona uygun şekilde İngilizceye aktarmış; İngiliz okurun kavram dünyasında yer almayan bu göstergeleri açımlama yoluna gitmiștir. Böylece hem Osmanlı kültürüne ait kavramları İngilizceye taşımış hem de İngiliz okur için bir okuma kolaylığı sağlamaya çalışmıştır. Eğer "St. Sophia" ya da "Olympos" adlandırmalarında olduğu gibi karşılaştığı nesne ya da varlığın daha önceden kullanılan ve İngiliz okurun aşina olabileceği bir karşılı̆̆ı varsa bu karşllkkları tercih etmiş ve özde çevirinin eğretilemesiz, gerçek anlamda bir çeviri, özde çeviri yazarının ise düz anlamda bir çevirmen, özde çevirmen (Öztürk Kasar, 2020, 21) olduğunu ortaya koymuştur. Pardoe'nun üçüncü çeviri stratejisi ise Osmanlı topraklarında gördüğü ve İngiliz kültüründe bulunmayan nesne ya da varlıkları benzeșim yoluyla Batı kültürüne aktarmaktır. Nitekim "Ramazan pidesi"nin İngilizcedeki "çörek" ile benzeşim kurularak "The Ramazan cake" olarak aktarılması ve Osmanlı saraylarında çalınan "kemençe" nin yine bir yaylı çalgı olan "zebec (rebec) " olarak aktarılması yapılan bu benzeșim işleminin birer göstergesidir.

Aslına çeviri metinler olarak ele alınan Türkçe çeviriler incelendiğinde ise çevirmenler Bedriye Şanda ve Banu Büyükkal'ın kent göstergelerini çıkış kültürüne çevirirken farklı tercihleri dikkat çekmektedir. Bedriye Şanda’nın çevirisi özde çeviri eserin kısaltılmış bir versiyonu olması nedeniyle Pardoe'nun aktardığı bazı göstergeleri içermemekte ve kimi göstergeler üzerindeki yazarın özde çevirisinin izlerini kapsamamaktadır. Bunun dışında her iki aslına çeviri eserde de Pardoe'nun İngilizceleştirerek yazdığı isimler Türkçe asıllarına çevrilerek Türk okurun aşina olduğu göstergelere dönüştürülmüştür. Yazarın İngiliz okura yabancı olan göstergeyi açıklamak için kullandığı tanımlamaların zaman zaman aslına çeviri metinlerde de yer aldığı görülmüştür. Özde çeviri metin ilk basımında 1837 yılında okuyucuyla

Adres Address

RumeliDE Dil ve Edebiyat Araştırmalar Dergisi $\quad$ RumeliDE Journal of Language and Literature Studies Osmanağa Mahallesi, Mürver Çiçeği Sokak, No:14/8 Osmanağa Mahallesi, Mürver Çiçeği Sokak, No:14/8 Kadıköy - İSTANBUL / TÜRKIYE 34714 Kadıköy - ISTANBUL / TURKEY 34714 e-posta: editor@rumelide.com e-mail: editor@rumelide.com tel: +90 505 7958124, +90 2167730616 phone: +90 505 7958124, +90 2167730616 
buluşmuş bir metindir ve aslına çevirileriyle arasında uzun yıllar bulunmaktadır. Dolayısıyla aslına çeviride bütüncenin yanı sıra zamanın da dikkate alınması önem taşıyan konulardan biridir. Nitekim yapılan karşılaştırmalı okumada "Mount Olympos” örneğinde olduğu gibi, özde çeviri metinde yer alan göstergenin Şanda tarafından Türkçeye yapılan çevirisinde, asıl dil ve kültürüne döndüğü ancak bu dönüşün günümüzdeki adlandırılmasıyla gerçekleştirildiği görülmüştür. Bu çeviri tercihinin okur için anlam taşıyan göstergeleri aktardığı ancak yazarın özde çevirisinin izlerini çıkış kültüre yansıtamadığı söylenebilir. Bunun yanı sıra yazarın benzeşim kurarak aktardığı göstergeler; aslına çevirilerde, ya yazarın özde çevirisinin izlerini korumak suretiyle doğrudan çevrilmiş ve çevirmenin parantez içinde sunduğu bir açıklama ile Türk okurun kavram dünyasında mevcut olan ismine döndürülmüş ya da metin içinde aslına çevrilerek bir dipnot ile özde çevirideki göstergeye ilişkin açılamaya yer verilmiştir.

Sonuç olarak Bassnett $(2004,75)$ 'ın da deyimiyle seyahatname ve çeviri doğası gereği gerçek ya da dilsel anlamda bir yolculuk içeren benzer metinlerdir. Yazarın mensubu olmadığı bir kültür-dile ait gerçekleri bu kültürün dışındaki kimselere naklettiği seyahatnamelerin ikincil bir çeviri işlemini daha bünyesine aldığı söylenebilir. Özde çeviri kavramı göstergelerin bu çok katmanlı dönüşümünü okumamıza olanak sağlamış, beraberinde getirdiği aslına çeviri kavramıyla göstergelerin aktarımında diller ve kültürler arasında yaşanabilecek aktarım sorunlarını görebilmemize imkân tanımıștır. Söz konusu kavramlar kullanılarak farklı metin türleri üzerinde yapılacak okumalarla, çeviriye ve çevirmene ilişkin mevcut tanımlamaların sorgulanması sağlanarak çeviribilime yeni ufuklar kazandırılabileceği düşünülmektedir.

\section{Kaynakça}

Asiltürk, B. (2009). Edebiyatın kaynağı olarak seyahatnameler. Turkish Studies. 4: 911- 995.

Barthes, R. (1993). Göstergebilimsel Serüven. ( çev. Mehmet Rifat, Sema Rifat). İstanbul: Yapı Kredi.

Bassnett, S. (2004). Travelling and translating. World Literature Written in English, 40(2): 66-76.

Beșe, T. (2017). Marmara'nın zirvesi Uludağ. Pttlife. ( Ed. E. Safi). Çankaya, Ankara. Büyükharf Bas. Yay. Tan. Dan. ve Org. Ltd. Şti.. ss. 20-27.

C.olakoğlu, G. \& Eken, M. (2009). Türk musikisi icrasında armudi kemençe ve geçirdiği teknik gelişmeler, 38. Uluslararası Asya ve Kuzey Afrika Çalışmaları Kongresi: ICANAS, Başbakanlık Atatürk Kültür, Dil ve Tarih Yüksek Kurumu, 179-193, (10-15 Eylül 2007), Ankara

Deniz, Ö. (2011). Cumhuriyet döneminde tatil kavramı ve 1935 tarihli ulusal bayram ve genel tatiller kanunu. Çağdaş Türk Tarihi Araștırmaları Dergisi, 11 (23) : 57-72

Ertuğrul, A. (2009). Hamam yapıları ve literatürü. Türkiye Araştırmaları Literatür Dergisi, 13: 241266.

Eynallı, E. (2014). Vakıf sever bir hanımsultan: Mihrimah. Restorasyon Ylllğı Dergisi, 9: 6-23

Küçükkaya, B. (2019). Galata Mevlevihanesi mezartaşları (Katalog-değerlendirme). (Yayımlanmamış Yüksek Lisans Tezi). Kırklareli Üniversitesi, Sosyal Bilimler Enstitüsü.

İkinci, A. (2014). Osmanlı'dan Cumhuriyet'e Ayasofya. (Yayımlanmamış Yüksek Lisans Tezi). Erzurum: Atatürk Üniversitesi, Atatürk İlkeleri ve İnkılap Tarihi Enstitüsü.

Öztürk Kasar, S. (2012). Traduction de la ville sous le point de vue sémiotique : Istanbul à travers ses signes en trois langues. In N. Rentel \& S. Schwerter (Dir.). Défis et enjeux de la mediation interculturelle . Frankfurt am Main: Peter Lang, 267-285.

Öztürk Kasar, S. (2020). Çeviri göstergebilimi ile kent göstergebiliminin bütünleşik bağlamında özde çeviri kavramının incelenmesi. Dünya Dilleri, Edebiyatları ve Çeviri Çalışmaları Dergisi, 1(1): $1-25$.

\footnotetext{
Adres $\mid$ Address

\begin{tabular}{r|l} 
Adres & Address \\
RumeliDE Dil ve Edebiyat Araştırmaları Dergisi & RumeliDE Journal of Language and Literature Studies
\end{tabular} Osmanağa Mahallesi, Mürver Çiçeği Sokak, No:14/8 Osmanağa Mahallesi, Mürver Çiçeği Sokak, No:14/8 Kadıköy - İSTANBUL / TÜRKIYE 34714 Kadıköy - ISTANBUL / TURKEY 34714 e-posta: editor@rumelide.com e-mail: editor@rumelide.com, tel: +90 505 7958124, +90 2167730616 phone: +90 505 7958124, +90 2167730616
} 
The transfer of the urban signs in The City of the Sultan and Domestic Manners of the Turks in 1836 as an example of watermark translation and in its retro-translations / S. Öztürk Kasar; K. Çelik (pp. 1067-1084)

Öztürk Kasar, S. (2021). Traduire la ville en filigrane: Istanbul par Georges Simenon dans Les Clients d'Avrenos. Vous avez dit littérature belge francophone? Le défi de la traduction, Catherine Gravet et Katrien Lievois (éds.), Frankfurt : Peter Lang, 235-266.

Pardoe, J. (1845). The City of the Sultan and Domestic Manners of the Turks in 1836, 3 vols. London: Henry Colburn.

Pardoe, J. (1967). Yabancı Gözü ile 125 yıl Önce Istanbul. (çev. Bedriye Şanda). İstanbul: İnkılap ve Aka.

Pardoe, J. (2017). Sultanlar Şehri İstanbul. ( çev. Banu Büyükkal). İstanbul: Türkiye İş Bankası.

Britanicca Ansiklopedisi. https://www.britannica.com/art/rebec.

Cambridge Online Sözlük. https://dictionary.cambridge.org/tr/s\%C3\%B6zl\%C3\%BCk/ingilizcet\% $3 \%$ BCrk\% 3 \% $37 \mathrm{e} /$ hermit.

Cambridge Online Sözlük. https://dictionary.cambridge.org/dictionary/english/creation.

Cambridge Online Sözlük. https://dictionary.cambridge.org/dictionary/english-turkish/the-sabbath.

İslam Ansiklopedisi. https://islamansiklopedisi.org.tr/sakal-i-serif.

İslam Ansiklopedisi. https://islamansiklopedisi.org.tr/sebt--yahudilik.

İslam Ansiklopedisi: https://islamansiklopedisi.org.tr/masallah.

İslam Ansiklopedisi: https://islamansiklopedisi.org.tr/bismillah.

TDK Sözlükleri. https://sozluk.gov.tr/.

Address

RumeliDE Journal of Language and Literature Studies

Osmanağa Mahallesi, Mürver Çiçeği Sokak, No:14/8

Kadıköy - ISTANBUL / TURKEY 34714

e-mail: editor@rumelide.com,

phone: +90 $5057958124,+902167730616$ 